\title{
Traditional State Functions, Their Specificity and Types: Historical Review and Socio-Cultural Characteristics
}

\author{
Valentin Ya. Lyubashits ${ }^{1}$, Alexey Yu. Mamychev ${ }^{2}$, Nikolai V. Razuvaev ${ }^{3}$, Alexander V. Osipov ${ }^{4} \&$ Natalya V. \\ Fedorova $^{5}$ \\ ${ }^{1}$ Department of Theory of State and Law, Southern Federal University, Russia \\ ${ }^{2}$ Department of Theory and History of Russian and Foreign Law, Vladivostok State University of Economics \\ and Service, Vladivostok, Russia \\ ${ }^{3}$ Department of Civil and Labor Law, North-West Institute of Management, Presidential Academy of National \\ Economy and Public Administration, Russia \\ ${ }^{4}$ Judge of Leninsky District Court Rostov-on-Don, Russia \\ ${ }^{5}$ Donskoy State Technical University, Russia \\ Correspondence: Alexey Yu. Mamychev, Department of Theory and History of Russian and Foreign Law, \\ Vladivostok State University of Economics and Service, Vladivostok, Russia. E-mail: mamychev@yandex.ru
}

Received: August 21, $2019 \quad$ Accepted: September 22, $2019 \quad$ Online Published: November 28, 2019

doi:10.5539/jpl.v12n4p70 URL: https://doi.org/10.5539/jpl.v12n4p70

The study was carried out with the financial support of the Russian Foundation for Basic Research in the framework of research project No. 19-011-31031

\begin{abstract}
The article analyzes the essence of the traditional state functions, their specificity and key differences in comparison with the activities and tasks of the modern state. Discussion of the differences and the argumentation of the types and specificity of the traditional state functions is carried out by the authors on the basis of systematization of various historical and legal studies, political and legal monuments. The article explains that it is possible for each traditional state to identify a number of special functions having historical and typological specificity and a specific historical characteristic. These special functions deepen and concretize the universal (general) function of the state, based on its purpose and thus embodying the essence of the state as a social institution. The authors demonstrate, in a specific context, that the functions of the traditional state as a "base core" form an affective and traditionalist orientation in public power; in contrast to the modern functions of the state, having a value-normative orientation and a goal-rational activity component.
\end{abstract}

Keywords: power, law, modern state, traditional state, state functions, evolution

\section{Introduction}

In the specialized literature, the state functions are understood as the main directions of its impact on social relations, based on the nature, essence, and social purpose of the state ${ }^{1}$. The functioning of the state is a rather complex and dynamic process, its theoretical comprehension requires considerable effort and causes serious disagreements among scientists ${ }^{2}$. At the same time, there are a number of opinions shared by almost all researchers to one degree or another. So, M.I. Baytin identifies four main characteristics of the state functions, including the following, firstly, the connection with the class (elite) and universal essence of the state, secondly, the expression of its active service role both inside and outside the country, thirdly, the historical determinism and variability of state functions and, fourthly, objectification in them of the most important socio-economic, political and spiritual patterns of social life ${ }^{3}$.

\footnotetext{
${ }^{1}$ Lyubashits Valentin Ya., Razuvaev Nikolay V., Mamychev Alexey Yu., Mordovtsev Andrey Yu., Magomedov R.M., (2018). State as Evolving Phenomenon: Key Problems and Approaches. Amazonia Investiga. Vol. 7. Julio-Agosto.Núm. 15: 32- 41.

${ }^{2}$ Lyubashits V.Ya., Mordovtsev A.Yu., Mamychev A.Yu. Theory of State and Law. Moscow: RIOR: INFRA-M, 2015.

${ }^{3}$ General theory of state and law. Academic course. (2007). In 3 volumes. / Ed. M.N. Marchenko. Ed. 3rd, reworked. and add.Vol. 1. State. Moscow. pp. 385-386
} 
L.I. Spiridonov explains the state functions as the main directions of its activity, "based on the objective need of people united by exchange relations to solve common affairs, determined by the character of the historically defined society", , and consistently focuses on their historical variability. According to many researchers, the state functions are historical, they "change at different stages of the society development, and also depend on changes in its socio-political system". In general, it is possible to agree with this statement using it in the study of various historical types' state functions. However, in our opinion, the thesis of historical determinism and, consequently, relativity of all functions without exception, needs a serious historical substantiation, which cannot be produced with the help of available empirical material. That is why it seems necessary to clearly define the ratio of the universal and particular, socially and historically determined aspects of the state functions in order to most fully take into account the last aspect while drawing up the typological characteristics of the state at various stages of its evolution.

\section{The Theoretical and Methodological Basis of Research}

At the moment, paraphrasing the words of K. Levi-Strauss, we have to admit that the idea of the historical variability of some state functions is a truism, the statements about changing of all functions without exception are absurd ${ }^{6}$. At the same time, it would be no less absurd (besides contradicting all available empirical material) that the state functions do not change at all during its evolution, as a result different historical types of states have the same set of predefined functions . Therefore, the position of V.E. Chirkin seems to us more persuasive. $\mathrm{He}$ distinguishes among the state functions "functions of a general nature, socially neutral, arising from" common affairs "and independent of social nature, type of state ... and socially determined, depending, in particular, on the historical type of state"

A state of any historical type realizes itself in activity and, therefore, has a functional basis showing unchanged aspects, being inherent to the state at all stages of evolution as a special phenomenon of social reality that differs from other phenomena. In other words, these universal functions (and only they) embody the essential characteristics of the state as an institutional expression of activity aimed at solving "common affairs". The most important of them, in our opinion, is maintaining the integrity of society by ensuring dynamic homeostasis of the processes occurring in it and meeting the common interests of individuals ${ }^{8}$. This function is general for all states at any stage of evolution and shows the social purpose of the state and, ultimately, its objective (essence) and subjective meaning.

Considering the above, we cannot agree with the sometimes expressed view that the functions of the state are aimed at maintaining the system integrity of the state itself ${ }^{9}$. This point of view has at least two shortcomings, namely, the state is considered, firstly, as a self-sufficient (and, therefore, closed) system and, secondly, as a phenomenon having intrinsic value in terms of its subjective meaning. Meanwhile, neither the first nor the second assumptions can be considered true. Undoubtedly, the state, like other social institutions, has internal orderliness, as well as a number of other system characteristics. This orderliness is the result of the construction of social reality in the activities of individuals, which was discussed earlier. However, the system characteristics of the state exist only as part of a more general system, namely the system of society as a whole ${ }^{10}$.

In other words, the state is not an independent closed system, but acts as one of the social subsystems. Consequently, its integrity directly depends on the integrity of the society, supported by the activity of the state. Therefore, it is impossible to talk about the intrinsic value of the state in a subjective sense, and no matter how many ideologists of totalitarianism try to give it such intrinsic value. Ultimately, the state's activity is assessed depending not on how this activity ensures its own existence, but on how it provides objective prerequisites for the existence of people. And thus it contributes to the consolidation of the historically determined measure of freedom in social interactions of people, which members of society have at all times, and to the expansion of this

\footnotetext{
${ }^{4}$ Spiridonov L.I., (2001). General Theory of State and Law, Moscow. p. 40.

${ }^{5}$ General Theory of Law and the State. (1996) / Ed. V. V. Lazarev. Moscow. 1996. p. 241.

${ }^{6}$ Levi-Strauss C., (2001). Structural Anthropology. Moscow. p. 2.

${ }^{7}$ Chirkin V.Ye., (2001). Modern state. Moscow. p. 201.

${ }^{8}$ Polyakov A.V., (2004). The general theory of law. Interpretation problems in the context of a communicative approach. St. Petersburg., $\mathrm{p}$. 548.

${ }^{9}$ Polyakov 2004; Lyubashits, V., Razuvaev, N., Mamychev, A., Shestopal, S., (2018). Signs of State and Their Historical Modifications. Journal of History Culture and Art Research, 7(3), pp. 175-186.

${ }^{10}$ Afanasyev V.G., (1980). Systemacy and society. Moscow.
} 
measure at subsequent stages of social evolution ${ }^{11}$. In our opinion, this is what gives the state its value and subjective meaning (especially the modern legal democratic state of the newest time).

\section{The Main Part}

The triune universal (general) function of the state belonging to it at any stage of evolution and arising from its very essence as the objective meaning of this social phenomenon consists in maintaining the systemic integrity of society, providing objective prerequisites for the existence of its members and securing a historically defined measure of freedom in social interactions. This function of the states of different historical types is specified as special, socially and historically determined functions, which are important typological characteristics of the states at a corresponding stage of evolution. In contrast to the universal, special functions are not directly related to the essence of the state, and therefore they do not remain unchanged with time.

Special functions of the state cover its typical features, therefore all states of the same historical type have a common set of such functions, and this set is clearly not the same for states belonging to different types (for example, traditional and modern states). In addition, even among states of the same type at the same stage of evolution, particular functions may vary depending on the particularities of their formal legal organization: the form of government, the state-territorial structure, and also depending on the particular political regime.

In other words, the set of special functions of the state is, firstly, historical and historically variable, secondly, determined with the general social conditions in which the state has to act, and finally, thirdly, it depends on the political and legal characteristics of the state of a certain type (historical subtype). To be convinced of this, it is enough to compare some functions of the traditional and modern states. In particular, the foreign trade function, almost not inherent to the modern state, occupied a very important place among the functions of the traditional state. Its significance is indicated, in particular, with the fact that in the Ancient East merchants engaged in foreign trade operations (for example, the Old Babylonian tamkars mentioned in the Hammurabi Laws) were equal to the royal servants and performed a number of duties to the king ${ }^{12}$. The archives of the ancient Asia Minor city of Kanisha studied by archaeologists ${ }^{13}$ indicate that even the merchants who were permanently residing in other states were subject to the authority of the ruler of their home country. Moreover, the foreign trade function of the ancient states was not only economic, but also political, since the possibility of entering into profitable trade deals depended on the political power and size of possessions of the Eastern Kings ${ }^{14}$. The most favorable from the point of view of foreign trade was the position of the rulers of large states, called "the great kings" $"$.

On the other hand, the defense function carried out by a traditional state was not monopolistic, but jointly with individuals and their associations. Only from the middle of the XV century, first in the countries of Western Europe and then in other regions of the world, it is fully concentrated in the hands of the state. It is noteworthy that at the same time, we can observe another process - active adopting gunpowder and firearms by the European armies of the late Middle Ages. It is known that the military use of gunpowder, invented by the Chinese in the 10th century, is described in one Arabic treatise dating from $1280^{16}$. However, in the East, gunpowder did not receive wide use for military purposes until the New Age. Moreover, even some cases of deliberate refusal of firearms are known. For example, in the middle of the XVI century, muskets actively used earlier were banned in Japan as incompatible with the samurai principles of warfare. As a consequence, the war in the states of the East continued to remain to a much greater extent a "private matter" than a function of the state ${ }^{17}$.

In Western Europe, gunpowder becomes known in the middle of the XIV century and, according to some data, was firstly using of the Western Europe was in 1324 in the war between England and France, by the end of which the use of firearms becomes systematic. And it is precisely at this time, according to historians, in a number of Western European countries (primarily in England and France) royal power begins to strengthen and

\footnotetext{
${ }^{11}$ Apolsky, E., Mamychev, A., Mordovtsev, A., Hasanova, Z., \& Shalyapin, S. (2018). State Legal Thought in Russia 19th - Early 20th Centuries in Monographs and Scientific Papers: The Experience of Systemic Examination. Journal of History Culture and Art Research, 7(3), pp. 347-352.

${ }^{12}$ History of state and law of foreign countries. (1998). Textbook. Part I / Ed. N.A. Krasheninnikova and O.A. Zhidkov. Moscow. p. 36.

${ }^{13}$ History of the Ancient East. The origin of the most ancient class societies and the first centers of slaveholding civilization. (1988). Part two. Front Asia. Egypt / Ed. D.M. Bongard-Levin. Moscow. pp. 46-5.

${ }^{14}$ Bedford P., (2001). Empire and Exploatation: The Neo-Assyrian Empire. Conference of Social Science History Institute Stanford University. May 21-22. 2001.

${ }^{15}$ Korovkin V.V., (2009). Essays on the history of the state economy, public finance and taxation in the ancient world. Moscow. pp. 148-149.

${ }^{16}$ Diamond D., (2010). Guns, microbes and steel. The history of human communities. Moscow. p. 311.

${ }^{17}$ Van Creveld M. (2006).The rise and fall of the state. Moscow.
} 
the transition from the traditional to the modern state with all its inherent functions, including the defense function, is activated ${ }^{18}$.

However, the final monopolization of the military function by the state occurs by the XVIII century, and among other factors influenced this process, in our opinion, the "victory of firearms over the crossbow", occurred, according to I.M. Dyakonov, in the XVI - XVII centuries, should be particularly highlighted ${ }^{19}$. In the modern world, as more and more deep and comprehensive introduction of high technologies into military affairs and the use of more and more sophisticated technical means, the defense function is completely monopolized by states and their associations because (whatever is claimed in the popular journalistic literature) individuals and organizations, as well as any institution of civil society are not able to perform it effectively enough in modern conditions.

When considering the special (socio-historically deterministic) functions of the traditional state having particular importance in terms of its typological characteristics, attention is immediately drawn to the fact that one of the main among them is the function of ensuring the land fertility, which had originally sacred character. The presence of this function in the earliest state formations is confirmed with the mythology. It was not by chance that, for example, the most peoples reached the stage of statehood were used to associating their rulers with domestic animals personified male potency (a bull, a horse or a donkey). It is well known, in particular, there is the widest distribution of the bull cult in the Ancient East and the islands of the Aegean Sea, for example, the well-known ancient Greek myth about the Minotaur.

First of all, it should be noted that in the ancient mythologies the image of the bull was associated with a wide range of meanings being of considerable interest in analyzing the functions of the traditional state. Thus, being the personification of physical power, the bull was considered as a protector, according to E.S. Danilov, it allowed him to act as a zoomorphic personification of public safety ${ }^{20}$. The bull was also considered as an animal, symbolizing fertility, and therefore fertility ceremonies of many nations included competitions with the bull, which probably developed from the ritual of human sacrifice. The most famous example of such competitions is the Cretan Tauromachy, scenes of it are adorned the walls of the royal palace at Knossos ${ }^{21}$.

In this regard, it is important to note that this cult was associated with the person of the king, who was symbolically identified with the bull-producer, the fertility of the land depended on its potency. This connection has very peculiar confirmation in the mentioned ritual of Tavromachy, the conclusion of it, according to some researchers, was the sacrifice of the bull $1^{22}$, and perhaps even devouring alive ${ }^{23}$. As is well known, J. D. Frazer, interpreting such rituals, brought them to the primitive practice of sacrifice of the sacred ruler in order to ensure fertility ${ }^{24}$.

However, according to Frazer, over time, as the royal power strengthened, the ritual deputy ruler begins to be used as a victim: first a man and then an animal ${ }^{25}$. Despite the fact that the concept of ritual regicide, proposed by Frazer, did not receive recognition and caused a reasoned criticism of scientists $^{26}$, who believed that there was no evidence of ritual regicide ${ }^{27}$, the fact of the close connection of the mythological image of the bull and

\footnotetext{
${ }^{18}$ History of the Middle Ages. (1990). In 2 volumes. / Ed. Z.V. Udaltsova and S.P. Karpov. vol. 1. Moscow. p.260.

19 Dyakonov I.M., (2010). Ways of history. From the most ancient person to our days. Ed. 3rd Moscow. p. 159.

${ }^{20}$ Danilov E.S., (2011). "The Julianus bull" as a symbol of securitas publica Problems of history, philology, culture. No. 31. P. 23-31.

${ }^{21}$ Malten L., (1928). Der Stiler in Kult und mystischen Bild. Jahrbuch des Deutshen Archäologishen Institut. Bd. 43. P. 136; Evans A. (1928). The Palace of Minos at Knossos. Vol. III. London; Persson A.W., (1950). The Religion of Greece in Prehistoric Times. Berkeley, P. 97; Lewy G.R., (1948). The Gates of Horn. London. P. 229; Willetts R.F., (1962). Cretan Cults and Festivals. London, P. 112; Schachermeyr Fr. (1964). Die Minoische Kultur des alten Kreta. Stuttgart. P. 138; Cameron M. (1987). The Palatial Thematic System in the Knossos Murals The Function of the Minoan Palaces / Ed. R. Hägg, N. Maritanos. Stockholm,. P. 325.

${ }^{22}$ Conrad J.R., (1961). Le Culte du Taureau de la prèhistoire aux corridas espagnoles. Paris; Pelon O., (1982). Le palais de Malia et les jeux de taureax. Rayonnement grec : Hommage à Ch. Delvote. Bruxelles. P. 55; 28.Burkert W., (1985). Greek Religion: Archaic and Classical. Oxford. P. 40; Marinatos N., (1986). Minoan Sacrifical Ritual. Stockholm, P. 42.

${ }^{23}$ Andreev, Yu.V., (1997). Minoan Tauromachy in the context of the Cretan myth cycle. MOYLEION. Collection of articles on the 70th anniversary of A.I. Zaitsev. St. Petersburg.. PP. 17-30.

${ }^{24}$ Frazer J.D., (1984). Golden branch. The study of magic and religion. Ed. 2nd, Moscow., pp. 253-270.

${ }^{25}$ Ibid, pp. 526-540.

${ }^{26}$ Lang A. 1901. Magic and Religion. London; Convey R.S., (1933). Ancient Italy and Modern Religion. Cambridge; Rose H.J. (1959). The Evidence for Divine King in Greece. Studies in the History of Religion. Leiden, Vol. 4. PP. 371-378; Marlow A.N.D., (1961). Myth and Ritual in Early Greece. Bulletin of the John Rylands Library. Vol. 43. PP. 373-402; Fontenrose J., (1966). The Ritual Theory of Myth. Berkeley; Kirk G.S., (1975). The Nature of Greek Myths. New York.

${ }^{27}$ Zaitsev A. I., (2003). Ritualistic killing of kings. Zaitsev A.I. Fav. articles. Vol. 2. St. Petersburg., p. 433-434.
} 
fertility (including land), on the one hand, and the royal power, on the other, does not cause any doubt.

This is confirmed with the relics of more ancient ritual practices preserved even in classical (and possibly Hellenistic) Greece within the framework of the most archaic cults one way or another connected with fertility. To make sure of this, it suffices to recall the rite of commemoration of Dionysus-Zagreus (see, eg: Firm. Mat. De err. prof. rel., $6,1-5)^{28}$, included the absorption of the meat of a torn alive bull. (homophagy) ${ }^{29}$. Probably, at first, this ritual was even more frightening, because, according to a number of ancient authors, it suggested human sacrifices and ritual cannibalism ${ }^{30}$. In this regard, it is appropriate to recall the famous myth about the murder of Pentheus the king of Thebes, who was torn into pieces by the worshipers of Dionysus (Apoll., III, 5, 2; 10, 8; Paus., II, 2, 7; Ovid. Metamorp, III, $710-731)^{31}$, which served as the basis for the tragedy of Euripides "The Bacchae" ${ }^{32}$.

The cult of the horse, also associated with fertility and with the state power, was no less widespread among Indo-European peoples in antiquity. This cult was widely spread in the Aegean region, and its inception, in all likelihood, occurs simultaneously with the emergence of the early states. Thus, in the Pylos kingdom of the II millennium BC, the supreme ruler (Wanaka) was the supreme priest of the deity Hippos. The goddess of Potnia (Mistress) was another supreme pantheon deity who patronized the royal power ${ }^{33}$. However, according to some scientists, Wanaka served as the high priest of the goddess Potnia, while the performance of acts of worship of God-horse was entrusted to lavaget - the second most important person after Wanaka ${ }^{34}$.

In archaic Rome, the horse was associated with the cult of the god of vegetation Consus, the female version of which was Opa, the goddess of abundance. The ancient Romans also regarded Consus as the saint patron of secret solutions ${ }^{35}$. It is possible that in archaic Rome the king himself was responsible for the performance of acts of worship of this deity and, therefore, Consus was associated with royal authority, as later - with consular powers. The image of the donkey is also associated with the image of the horse, which, however, was ambivalent On the one hand, in both Eastern and Western cultures, the donkey was also a symbol of fertility and was associated with the ruler, and likening the donkey to the king was intended to emphasize the sacral function of the latter as a carrier of potency, having a stimulating effect on the harvest.

A typical confirmation of this is found in Commodus's biography from the collection of Scriptores historiae Augustae (SHA. Commod, 10, 9), which says that the emperor "spent a lot of time in the company of a man, whose generative organ was larger than most animals. He was very fond of this man, calling him his donkey, and even appointed the cult priest of the Rural Hercules " ${ }^{~} 36$. These words, in our opinion, shed light on the shocking behavior of some emperors, for example, Commodus or Heliogabal (Elagabal), whose antics, looked outrageous in the eyes of secularized Roman society, find a well-known explanation in the context of Eastern fertility cults ${ }^{37}$.

On the other hand, the ambivalence of the donkey's image leads to the fact that in the late antiquity era, the donkey's image begins to correlate not with the king, but with his ritual substitute, and later with the usurper of the throne, that is why donkeys are used in rituals of punishment of those who tried to usurp supreme power. It is noteworthy, in particular, the message of Polybius (Polyb., VIII, 23) about the massacre of the challenger to the throne of the Seleucid state, Acheus, captured in Sardis and executed by order of the king Antiochus III in 214 BC. Acheus was cut off the fingers and toes and head, and then sewn up in a donkey skin and crucified on a cross.

Thus, in our opinion, done analysis convincingly enough confirms the idea expressed earlier that from ancient times the most important function of the traditional state was the function of maintaining fertility through the

\footnotetext{
${ }^{28}$ Firmici Materni de errore profanarum religionum, (1970). Transl. by C.A. Forbes. New York,

${ }^{29}$ Andreev (1997). Minoan Tauromachy in the context of the Cretan myth cycle, p. 25.

${ }^{30}$ Losev A.F., (1996). Mythology of the Greeks and Romans. Moscow., p. 165

${ }^{31}$ Lyubker F., (2001). Real Dictionary of Classical Antiquities. Moscow. In 3 vol. Vol.3. P. 44.

${ }^{32}$ Euripides. (1999). The Bacchae .Euripides. Tragedy. In 2Vol. Vol. II. Moscow. pp. 650-652.

${ }^{33}$ Polyakova G.F. (1983). Greek societies of the 2nd millennium BC. Ancient Greece. Problems of development of the policy. Vol.1. The emergence and development of the policy. Moscow. P. 61.

${ }^{34}$ Palmer L., (1969). The Interpretation of Mycenaen Greek Texts. Oxford, P. 86, 92, 191.

${ }^{35}$ Dumezil G. (1969). Idees Romaines. Paris.

${ }^{36}$ SHA. Commod, 10, 9: Habuit et hominem pene prominente ultra modum animalium, quem Onon appellabat, sibi carissimum. Quem et ditavit et sacerdotio Herculis rustici praeposuit. - Scriptores Historiae Augustae. (1921). Vol 1. New York, P. 290.

${ }^{37}$ Chernikova E.M. (2008). The borrowing of theonyms and deonyms in Indo-European languages. Bulletin of the South Ural State University. Ser .: Linguistics. № 16. P. 10-11; Mostovshchikova E.A., (2009). Sacralization of power in the Roman Empire and the cult of the sun. Bulletin of the Leningrad State University named after A.S. Pushkin. Vol. 2. No. 3. P. 190-191.
} 
performance of acts of worship. At first, another important function, belonged to the traditional state, was firstly associated with the aforesaid function, namely, ensuring land ownership and protecting land ownership rights. This function is already reflected in ancient Eastern legislative monuments, among which the ancient Indian legislation provides a particularly rich material for study ${ }^{38}$.

Thus, it is said in Arthashastra (I, 13), that kings "deliver to the subjects the safety of possession of property"39. The regulations on the duties of a ruler formulated in the Laws of Manu (ML, VII, 2-3) are similar in meaning. Therefore, the tasks of the ruler included the administration of justice (ML, VIII, 1, 10), custody of minors, mad and widows (VIII, 27, 28), etc. ${ }^{40}$. Similar statements can be found in other ancient Indian sources, for example, "Baudhayanadharmashastra" (I, 10, 18) says: "Let the king protect his subjects, receiving one-sixth as a reward." The relationship between the ruler and the subjects was transferred in private mutual obligations. The significant role of the state in the protection of property rights to land is also confirmed with Middle Assyrian laws (see: MAL I, 8-9) and other monuments of ancient Eastern legislation, but this function is most clearly manifested in the ancient polis state.

There is a clear contradiction during its implementation, based on the specifics of this historical type of state, as was shown earlier, being the sovereign owner, whose political dominance was based on private law basis. As a result, the traditional state primarily protected not the public (public) but its own interest, which was often given priority over the interests of members of society. Such a "conflict of interest" was fraught with conflicts, often resolved by force, which made traditional states very unstable. The severity of social contradictions was significantly reduced in democratic republics, like Ancient Athens, where the interests of the state largely coincided with the interests of citizens. However, even here, complete coincidence could not be achieved due to the fact that the civilian collective in such republics was a minority compared to non-civil society members.

So, for example, in Attica on the eve of the Peloponnesian War (431 BC), according to well-known calculations ${ }^{41}$ of Ed. Meyer, for about 250 thousand inhabitants accounted for about 30-40 thousand citizens ${ }^{42}$ i.e. only every sixth person had full civil rights. The situation was much more acute in those traditional states, in which only the owners of land plots being part of the communal agrarian foundation had civil rights, for example, Sparta. Here the number of full citizens in the VI - V centuries BC was 9000 families according to the number of land plots created during the lycurgic reform (see: Plut. Lyc., 8$)^{43}$, despite the fact that the population of Laconia was hardly inferior to Attica. Over time, the number of Spartan citizens has steadily decreased as the redistribution of the agricultural fund and the concentration of land in the hands of the wealthy Spartans. So, on the eve of the battle of Leuctra (371 BC) the number of full Spartan citizens did not exceed 1,000, and by the middle of the III century BC it was reduced to 700 people.

The sharp decline in the civilian collective caused a catastrophic fall in the political and military power of Sparta, as well as a number of other ancient policies, for which this was, according to sources, a very serious and almost insoluble problem. Even in the Roman Republic, whose territorial growth was accompanied by a constant increase in the number of citizens, the population of the provinces in the vast majority did not have civil rights. A similar situation persisted in the early years of the principality (the end of the I century BC): in particular, in XIV $\mathrm{BC}$, the total number of citizens was 4,937,000 people, of which the lion's share $(4,100,900$ people) accounted for the population of Italy ${ }^{44}$. Only in the first centuries of the Empire (I - II centuries AD) the wide provision of civil rights to provincials occurs. However, since at that time the state ceases to be, in accordance with the famous definition of Cicero, "common property" and becomes the personal property of the princeps, an

\footnotetext{
${ }^{38}$ Bongard-Levin, G.M., (2003). On land ownership in ancient India. Bongard-Levin G.M. India. Ethnolinguistic history, political and social structure, written heritage and culture of antiquity. Moscow;

39 Arthashastra, or the science of politics (1993). / Ed. V.I. Kalyanov. Moscow.

${ }^{40}$ Vigasin A. A., Samozvantsev A. M., (1984). "Arthashastra" (problems of social structure and law). Moscow; Lelyukhin D.N., (1998). The concept of the ideal kingdom in "Arthashastra" Kautilya. State in the history of society (to the problem of criteria of statehood). Moscow.. pp. 8-143.

${ }^{41}$ Lentsman Ya.A., (1963). .Slavery in Mycenaean and Homeric Greece. Moscow.,

${ }^{42}$ History of Ancient Greece (2003). / Ed. V.I. Kuzishchina. Ed. 3rd. Moscow., p. 173

${ }^{43}$ Pechatnova L.G., (2002). The history of Sparta (the period of archaic and classical). St. Petersburg., P. 29-64.

${ }^{44}$ Ehrenberg V., Jones A. H. M., (1949). Documents Illustrating the Reigns of Augustus and Tiberius. Oxford, P. 40; Mashkin N. A. (1949). Principate of Augustus: origin and social essence. M .; L., P. 458; Brunt P. A., (1971). Italian Manpower 225 B. C. - A. D. 14. Oxford, P. 119; Lo Cascio E., (1994). The Size of the Roman Population: Beloch and the Meaning of the Augustan Census Figures. Journal of the Roman Studies. LXXXIV. P. 29.
} 
increasing the number of citizens does not lead to a coincidence of the state and public interest ${ }^{45}$. The traditional states of the Middle Ages and the early Modern period faced similar problems, and only the transition from the traditional state to the proto-modern and then to the modern created the prerequisites for overcoming the fundamental contradiction between public and state interests in the implementation of the state functions in solving common problems.

The traditional state possessed another special historical function (in particular, the ancient polis state) consisted in expanding the agrarian fund, which belonged to the state on the basis of supreme property. Solving this problems was intended to ensure the reproduction of a civilian collective and, moreover, not simple reproduction, but more or less steady increase, because the growth of state power depended on it. The necessary condition was the vesting of new citizens with land, which could be carried out only with the use of the agrarian fund of the community; therefore it should be continuously replenished. This circumstance attached particular importance to the function of protecting and expanding the agrarian fund, closely related to the military (defensive) function of the traditional state. Acting as the bearer of the right of supreme ownership of land, the traditional state naturally acquired the function of protecting property, and the military function (defense function), it seems to us, was a kind of continuation of the last one.

We find very eloquent testimony in the biography of Pescennius Niger, where, as an example of the reckless behavior of the usurper Didius Julianus, it is reported that "he was said to have filed a lawsuit against Septimius Severus regarding the imperial power on the basis of Lex Aquilia to make it seem that he became a sovereign before Severus by right" ${ }^{\text {"46 }}$. This message looks completely implausible, because for the modern sense of justice it is absolutely unimaginable situation, when public law is protected with an act provides property rights. In the context of a mixture of private and public law, being usual for the traditional law and order, that's why a person who was familiar with legal procedures could have such a temptation. Thus, Didius's recklessness was not that he "counted in the dispute over power to rely on an act that was valid only in the area of private law relations" commentators believe, but only that he tried to resolve the dispute by legal means, while it could be solved only by force.

Of course, it would be a mistake to believe that the traditional state protected only property relations. Monuments of legislation show that in all traditional societies the protection of the state also extended to the individual. However, most often the individual itself acted as a continuation of property (because a clear differentiation of the subject and objects of law took place only in the New time $)^{48}$, measures of protection were carried out in the framework of this function. It is not by chance that in all corpuses of criminal law - from the Hammurabi Laws to Caroline, there is a very clear differentiation of the severity of criminal liability depending on the social (and, as a result, property) position of the criminal and the victim ${ }^{49}$.

If we talk about a number of those functions that are inherent to the modern state, the traditional state provided them either jointly with other social institutions, or occasionally as the same supreme owner of the land, and therefore they cannot be considered as functions in the proper sense of the concept $\mathrm{t}^{50}$. First of all, it concerns the social function, which occupies such an important place in the activities of the modern state. It is easy to see that all the activities of a modern state included in the content of its social function generally fit into the concept of providing public services, if it is interpreted quite broadly ${ }^{51}$. At the same time, it is quite obvious that such public services were completely alien to the traditional state. Even those single facts, when the state was still taking care, for example, about the regulation of wage rates for employees or the prices of goods and services were not explained at all by the desire to systematically regulate social processes, but were dictated by one or other extraordinary circumstances.

\footnotetext{
${ }^{45}$ Schetinnikov M.N., (2004). Emperor Augustus and the spread of Roman citizenship in the provinces. Mnemon. Research and publications on the history of the ancient world / Ed. E.D. Frolov. Issue 3. St. Petersburg., P. 304

${ }^{46}$ SHA. Nig., 2, 6-7: Denique etiam Aquilium centurionem notum caedibus ducum miserat, quasi imperator tantus a centurione posset occidi. Par denique insania fuit, quod cum Severo ex interdicto de imperio egisse fertur, ut iure videretur principatum praevenisse. Scriptores Historiae Augustae. Vol 1. P. 432.

${ }^{47}$ The Lords of Rome. Biographies of Roman emperors from Adrian to Diocletian. St. Petersburg., 2001. P. 339.

${ }^{48}$ Razuvaev N.V., (2007). The subject of law as a historical and cultural category . Yearbook of libertarian-legal theory. Researches of scientists of the Russian libertarian law school, academician V.S. Nersesyants / Ed.- comp. V.A. Chetvernin. Issue 1. p. 59.

${ }^{49}$ Pashukanis E. B. (198)0The general theory of law and Marxism. Experience of critics of basic legal concepts. Pashukanis E. B. Selected works on the general theory of law and the state. Moscow. pp. 32-181.

${ }^{50}$ Kechekian S.F. (1944). General History of State and Law. Part I. Vol. 1. Ancient East and Ancient Greece. Moscow., p. 190; Kechekian S.F. (1947). Aristotle's theory of the state and law. Moscow, p. 65-68.

${ }^{51}$ Public services: legal regulation (Russian and foreign experience) (2007)./ ed. E.V. Grishchenko and N.A. Shevelevoy. Moscow.
} 
For example, Diocletianus's edict about maximum prices from 301, in which the maximum prices for goods, works and services throughout the empire were set $^{52}$. It seems, however, that such events were associated with the implementation not of a social function, but of the same function of protecting property. However, life practice confirmed the unrealistic nature of these events under the conditions of that time ${ }^{53}$. The attempt of Hammurabi to fix in his laws the fixed size of the salary paid to workers was equally unrealistic (see: LH, $\S 239$, 257-258, 261, 268, 273-274). These tariffs also cannot be considered as manifestations of the social function of the state, if only because the same rules concern the amount of payment for hiring things (LH, §242-243, 269, 272 , etc.).

In addition, V.G. Child noted: "According to the decree ... of Hammurabi (meaning the laws of Hammurabi, - N. R.) and later decrees of the Hittite and Assyrian monarchs the maximum prices and maximum, not minimum payments were set at ... So throughout the bronze century middle class remained completely dependent on the monarchy and the priests $^{\prime \prime 5}$. Thus, the attempts of the traditional state to regulate the level of prices and wages centrally led not to an increase in the social protection of members of society, but to directly opposite results, namely, to an increase in the degree of their dependence on the state. This obviously prevents their identification with the social function of the modern state.

In general, it can be stated that in a traditional society the satisfaction of certain social needs of its members has always been carried out either by those structures into which they were integrated, or by private individuals in the order of charity. Manifestations of such social care are already known at the earliest stages of human history ${ }^{55}$. The prerequisites for its birth should be sought in the customs that existed among many primitive tribes, which were supposed to support intracommunal solidarity. One of the most famous examples of this kind is the famous Potlatch, studied by M. Moss ${ }^{56}$. M. Moss convincingly proved that in a primitive society the exchange of gifts was the basis of exchange relations between its members, contributing to the satisfaction of their basic needs. Thus, the deed of exchange acted in the function of mutual aid, but it was not disinterested, because in the end it entailed the establishment of the personal dependence of some tribesmen on others. Having originated within the clan community, mutual assistance (including in the form of a gift exchange) retains the significance of the basis of social ties and with the transition from the clan community to the neighbor community ${ }^{57}$, providing a more uniform distribution of benefits within $i^{58}$.

At the same time, mutual relations in peasant communities were albeit informal but so strong and binding that it gave rise to J.M. Foster to denote them by the term "dyadic contract" generally speaking, by a relatively low level of intracommunal solidarity, and this is what distinguishes it, for example, from the polis (civil society), cohesion of its members was extremely high ${ }^{60}$.

That is why precisely in ancient times along with measures undertaken by the community itself to support its members ${ }^{61}$, private charity is becoming widespread ${ }^{62}$. It is also well known what role mutual support played in a feudal society, especially in relations between representatives of the feudal class, built, as is known, on the principle of loyalty ${ }^{63}$. Medieval West European (in particular, English) law also regulated the duties of a vassal in relation to the seigneur, in particular, to assist the latter in difficult situations. In accordance with art. 15 of the Magna Carta of 1215,

\footnotetext{
${ }^{52}$ Christ C. (1997). The history of the times of the Roman emperors from Augustus to Constantine. Rostov-on-Don., Vol. 1. p. 399.

${ }_{53}$ Rostovtsev M.I. ( 2001). Society and economy in the Roman Empire. St. Petersburg, Vol. II. p. 222.

${ }^{54}$ Child G. (2012). The heyday and fall of ancient civilizations. The distant past of mankind. Moscow., P. 212

${ }^{55}$ Semenov Yu.I. (1976). Primitive Commune and Neighborhood Peasant Community. Formation of Classes and the State / Ed. ed. A.I. Pershits. Moscow., pp. 49-57.

${ }^{56}$ Mauss M. (1983).Essai sur le don. Forme et raison de 1’ echenge dans le societes archaique. Mauss M. Sociologie et anthropologic 8-eme ed. Paris,

${ }^{57}$ Averkieva Yu.P. (1961). Decomposition of the tribal community and the formation of early class relations in the society of the Indians of the northwestern coast of North America. Moscow, pp 128-135.

58 Bennett G. M. (1968). Reciprocal economic exchange among North American agricultural operator. Southwestern Journal of anthropology. Vol. 2, № 2 .

${ }^{59}$ Foster G. M. (1961). The dyadic contract: a model for the social structure of a Mexican peasant village. American Anthropologist. Vol. 63, № 6.

${ }^{60}$ History of the East. (2002). In 6 volumes. Vol. 1. East in antiquity / Ed. V. A. Jacobson. Moscow., p. 226; Ancient Greece. Vol. 1 p. 31.

${ }^{61}$ Pringsheim F. (1950). The Greek Law of Sale. Weimar, P. 233; Bloch H. (1940). Theophrastus Nomoi and Aristotle. Harvard Studies of Classical Philosophy. Cambridge (Mass.), Supplem. 1. P. 366; Ehrenberg V. (1969). The Greek State. London, P. 39; Oliva P. Sparta and Her Social Problems. Princeton, 1971. P. 37-38

${ }^{62}$ Andreev V.N. Agrarian relations in Attica in the 5th - 4th centuries. BC. Ancient Greece. Vol 1. P .297

${ }^{63}$ Koenigsberger G. ( 2001). Medieval Europe. 400-1500 years. Moscow. pp. 114-115
} 
the vassal was obliged to provide funds for the purchase of the seigneur from captivity, for the knighthood of the first-born son of the seigneur, and for the marriage of his firstborn daughter ${ }^{64}$. However, "after the adoption of the Magna Carta, some English lawyers (for example, Brakton) believed that vassals assist the seigniors out of mercy and not according to duty (de gratia non de iure) ${ }^{365}$. The same reciprocal obligations of mutual assistance were related to members of city corporations - guilds and workshops ${ }^{66}$.

Similar relations developed between representatives of not only the same, but also of different classes, in particular between peasants and the feudal lord. The latter, according to the ideas widely spread in the Middle Ages, was obliged to provide patronage, commendation to the peasants living on his land and personally dependent on him. However, as D.M. Petrushevsky showed in his research, the development of feudal land tenure did not entail the destruction of the peasant community ${ }^{67}$. Thus, up to the late Middle Ages, the peasant (even feudal-dependent) was integrated into the community, which ensured the satisfaction of his basic necessities of life.

It is not surprising that under such conditions the social function of a traditional state (or rather, what we, besides with a very significant degree of modernization, are called "social function") manifested itself only sporadically and also in the form of all the same personal charity. Very typical example is the good deeds that turned Eastern monarchs to their subjects. To see this, it is enough to recall, in particular, the grand feast, organized by the Assyrian king Ashur-natsir-Apal II in $879 \mathrm{BC}$ on the occasion of the consecration of the new palace in the city of Kalkh, which was attended by at least 70 thousand people ${ }^{68}[83$, p. 352]. Similar situation was in other monarchies of antiquity, for example, in imperial Rome, rulers in their activities continued the policies of the Hellenistic monarchs of the East with their orientation to "soteria" and "evergesia".

In this connection, the words of Antoninus Pius that "after we were called to rule the empire, we lost what we had before" become quite understandable ${ }^{69}[84$, p. 108]. There is the story about Antoninus's successor, Marcus Aurelius (see: SHA. Mac, 17, 4), having exhausted the state treasury during the war, he organized a sale of his personal property to replenish it. The medieval monarchs also did not shun acts of charity, furnished with great pomposity. Thus, according to Gregory of Tours (Greg. Thur. Hist. Franc, V, 23), the king of the Franks, Jilperich I, in 579, on the occasion of the death of his son, destroyed the tax lists of his subjects.

\section{The Conclusion}

Thus, all the special functions of a traditional state considered in this paragraph, reflecting its historical and typological specificity, on the one hand, deepen and specify the universal (general) function of the state arising from its purpose and thereby embodying the essence (objective meaning) of the state as a social institution. On the other hand, these functions are socially determined and based on the historical originality of traditional society as a predominantly agrarian society. It follows, firstly, that they were anyway connected with the land and aimed at satisfying the socially important needs of members of society as owners of the land and, secondly, that the state implemented them based on its authority as the supreme owner of land. In addition, it is impossible not to draw attention to the explicit (especially at the early stages of the historical development of a traditional state) sacral nature of these functions, that makes it possible to see them, using the terms of M. Weber, not as $a$ purposeful activity (similar to the functioning of a modern state), but as activity affective and traditional, in our opinion, it is another characteristic historical feature of these functions.

\section{Copyrights}

Copyright for this article is retained by the author(s), with first publication rights granted to the journal.

This is an open-access article distributed under the terms and conditions of the Creative Commons Attribution license (http://creativecommons.org/licenses/by/4.0/).

\footnotetext{
${ }^{64}$ Monuments of the history of England XI - XIII centuries. (1936). Moscow., p. 103.

${ }^{65}$ Venediktov A.V. (2004). State Socialist Property. Venediktov A.V. Fav. works in civil law. In 2 volumes. Vol. 2. Moscow., p. 150.

${ }^{66}$ Gurevich A. Ya. (1999). Categories of medieval culture. Gurevich A. Ya. Fav. works T. 2. The medieval world. Moscow., St. Petersburg, p. 169.

${ }^{67}$ Petrushevsky D. M. (2003). Essays from the history of medieval society and the state. Moscow., p. 409.

${ }^{68}$ Gulyaev V.I. (2005). Schumer. Babylon. Assyria. 5000 years of history. Moscow., p. 352.

${ }^{69}$ SHA. Ant. Pius., 4, 8: ... posteaquam ad imperium transivimus, et illud quod habuimus ante perdidimus. - Scriptores Historiae Augustae. Vol 1. P. 108 .
} 